\title{
The Correlation between Grit and Leadership: A Longitudinal Study
}

\author{
Leonard J. Samborowski \\ Nichols College, Dudley, Massachusetts, USA \\ Leonard.samborowski@nichols.edu \\ Jay Price \\ Nichols College, Dudley, Massachusetts, USA \\ Jason.price@nichols.edu \\ John Pratico \\ Anna Maria College, Paxton, Massachusetts, USA \\ Jpratico@annamaria.edu
}

DOI: 10.47299/bsjmm.v2i1.63

\begin{abstract}
This longitudinal study, conducted on a college campus, examines the correlation of grit to leadership from a behavioral theory perspective through four variables: passion, perseverance, self-awareness, and ethical behavior. The study found an increase in grit scores over time. Higher grit scores were found for students when they were seniors than when they were freshmen. Overall, there were positive and significant linear correlations between self-perceptions of grit and self-perceptions of leadership, including positive correlations between variables of grit (passion and perseverance) and variables of leadership (self-awareness and ethical behavior). The relationships between perseverance and self-awareness were the strongest, while that of perseverance and ethical behavior came in second. The study concluded that perceptions of grit and leadership ability are strengthened by the college experience.
\end{abstract}

Keywords: leadership, grit, self-awareness, ethical behavior, passion, perseverance

\section{Introduction}

In July of 2014, a longitudinal research study was initiated at Nichols College, a small, private business school in Dudley, Massachusetts with 1,100 students. Nichols was chosen because of the leadership focus of the college. While it is acknowledged that a core function of higher education is the education and development of future leaders (Astin, 1993; Tyree, 1998), Nichols includes this focus as its raison d'etre. The mission statement of Nichols College states: "transforms today's students into tomorrow's leaders" (Appendix A). The emphasis of leadership in the institution's mission statement echoes the intent of many other colleges and universities (Colgate University, 2020; Dartmouth College, 2020; Daemen College, 2020; Harvard College, 2020; McDaniel College, 2020; Occidental College, 2020). Additionally, leadership course development at the college is congruent with the recent (since 2000) increase of curricular and co-curricular programs targeting college student leadership development (Dugan, 2007).

What makes Nichols College distinctive and relevant to grit/leadership research is the small size and status as a not-for-profit, private business school. The demographic data from this longitudinal study provides a special category, a majority-based sample, for comparative future research. The research study participants included, approximately $65 \%$ male, $82 \%$ white and $93 \%$ from New England 
(Admission Office, 2020). Using this base, it is easy to imagine a mirrored study that juxtaposes data correlations with a college comprised of a larger, more diverse student body.

This study offers a data-backed assessment of the effectiveness of a leadership focused curriculum at a small, private business school in New England. The authors contend that leadership is not a person or single action but rather a behavioral process of influence. Accordingly, it was important to measure the behaviors of the leadership process. Grit, comprised of perseverance and passion, and the selfawareness and ethical behavior aspects of leadership were variables of interest.

\section{Literature Review}

"The understanding of leadership has figured strongly in the quest for knowledge" (Bernard Bass, 1990, p. 3), and is therefore closely aligned with the intent of higher education. Since social science research began in the $19^{\text {th }}$ Century, studies on leadership have emerged in every academic discipline (Bornstein, 1999; Northouse, 2012). Each one requires a clear definition of concepts planted within a theoretical framework (Stenius, 2017). Recognizing that there are as many "definitions of leadership as there are persons who have attempted to define the concept" (Schriesheim \&Kerr, 1977; Rost 1993), it was important to choose a definition that was aligned with the mission of the school. In choosing the definition that leadership is "the process of influence toward goal achievement" (Stogdill, 1950 , p. 2), numerous theoretical frameworks were evaluated. Trait, Situational, Relational and Behavioral theories were considered in the development of this study.

\section{Trait Theory}

Studies of trait theory were especially prominent from the 1900 s to 1940 s and may be considered as the earliest approach to conceptualizing leadership for social research (Antonakis, Cianciolo, \& Sternberg, 2004). The theory posits that individuals possess traits that influence leader emergence and effectiveness (Colbert, Judge, Choi, \& Wang, 2012).

Trait theory has provided scores of characteristics associated with effective leadership. In the 1980s, the psycholexical approach to personality assigned five "Big Personality Factors" that included openness, conscientiousness, extraversion, agreeableness, and neuroticism (Raad, 2000). Judge and Long (2012) analyzed the leadership benefits and costs of manifested bright (amicability) and dark (narcissism) traits. Robert House (2013) listed 22 desirable leadership attributes, eight of which were universally desirable and 35 which were culturally dependent.

While the trait theory was a contender to serve as the framework for this research (in that students from disparate geographies and cultures bring their unique traits to the academic community), it was rejected because it implies an elitist view of leadership. Possessing leadership traits suggests a propensity to lead, absent the traits, to follow. Finally, literature found that the trait theory lost its legitimacy with social researchers, notably Stogdill (1950), who found that both person and situation had to be studied to understand leadership.

\section{Situational Theory}

Supported by the works of Hersey \& Blanchard (1969), Reddin (1967), and Vecchio (1987), the situational theory posits that the leader appears as a product of situations and circumstances (Stogdill, 
1975). Proponents of the Situational theory advance the view that leaders emerge and are directed by the historical moment, i.e., the situation (Murphy, 1941).

Like trait theory, the situational theory was rejected as it pays insufficient attention to leadership development and personal growth, which are common and expected processes of the college experience (Dary, 2012). Additionally, the authors find the relatively non-historic rite of passage that is college matriculation, not congruent with the perspective that leaders arise from the current zeitgeist.

\section{Relational Theory}

Supported by the works of Exchange Theories social scientists (Blau, 1964; Burns, 1978; Gergen, 1969; Homans, 1958; March \& Simon, 1958; Thibaut \& Kelly, 1959), the relational theory focused on the nature of relations between leaders and followers. A significant advocate for this theory was Graen (1976) and his Leader-Member Exchange (LMX) model. The LMX model predicted that high-quality relations generate more positive organizational outcomes than low-quality ones. Therefore, leaders should improve follower motivation to enhance performance. Another model resident within the relational theory is the Contingency Model, which emphasized the importance of the perception of team membership (Alutto \& Acito, 1974; Miller \& Monge, 1986). This theory was intriguing because of the importance of peer validation among college students (Hopmeyer et al., 2017).

The relational theory offered several foci compatible with this study. The interaction and collaboration of college students is a standard objective in the design of most college curricula (Richardson, et.al, 2019). Likewise, encouraging positive transactions to increase performance quality and product quantity are of interest to all college professors. Recognizing each student as an important part of the campus team validates the individual and encourages an inclusive environment, which is longed for on every college campus. However, the relational theory was also rejected as a more action focused and introspective theory was sought.

\section{Behavioral Theory}

A theory that gained prominence in the late 1930s with studies conducted at Ohio State University and the University of Michigan in the 1940s, the behavioral theory looked at how leaders behaved in small group situations. Simply put, "leadership is what leaders do when they are in a leadership role" (Northouse, 2018). This theory contends that leadership is internally self-observable and externally observable by others (Yukl, 1971; Conger, 1987). This observation, especially the self-observable condition, was important to this study.

Behavioral models of leadership point to two forms of general behavior: performance-oriented behavior and relationship-oriented actions (Padyk, 2017). Performance-oriented behavior is focused on task completion. In a college environment, this behavior manifests through actions like writing a paper, developing a presentation, completing an internship, and earning a grade of "A." Relationshiporiented behaviors are employed by leaders to build comfort with peers, competitors, and general environments and situations (Northouse, 2018). In a college setting, relationship behaviors are displayed as students adapt to new living arrangements, join clubs, and vie for acceptance on athletic teams. For these reasons, the behavioral theory was selected as the framework for the research design. 


\section{Research Variables and Behavioral Theory}

Four variables of behavior were of interest to the research authors: passion, perseverance, selfawareness, and ethical behavior.

\section{Passion and Perseverance}

Passion and perseverance were of interest as they are the identified sub-components of grit (Park, 2020). Duckworth (2020) contended that grit is more important than talent, intelligence, or social background as a predictor of career achievement. Therefore, it is a potential determinant of college success. The passion component of grit can be understood as an interest extended over time. It is not necessarily a conscious pronouncement or written declaration, but more of a high-level, abstract commitment to an end state. It is an unconscious vision that points in one direction. Students that routinely change their interests, major or course of study, are less likely to be successful as they are always starting over. Because it takes quantity and quality to achieve passion, fluctuation distances one from greatness (Duckworth, 2020).

Perseverance, in turn, is biased toward the completion of one's passion. In short, how hard will a person work to achieve their chosen end-state? Pinned to academics, can a student overcome poor grades or even a course failure in order to conquer the challenges of an undergraduate degree (Palisoc, et al., 2017). The Duckworth perspective that grit is comprised of passion and perseverance, is congruent with the perspectives of the authors of this study.

\section{Self-Awareness and Ethical Behavior}

The variable of self-awareness is important in leadership studies as it echoes the admonishment of Socrates to "Know Thyself" (Meens, 2013) as a first step in the beginning of wisdom of any kind (Green, 2018). In fact, numerous leadership scholars contend that leadership is a process of self-discovery (Haas, 1992). Kouzes and Posner (1987) wrote that the "quest for leadership is first an inner quest to discover who you are" (p. 298). Accordingly, self-awareness, derived from self-reflection is a prerequisite to understanding leadership development.

Ethical behavior was selected as a research variable for several reasons. Over the last 20 years, business scandals have drained billions of dollars and value from the corporate world and consumers' pockets. Infamous names like Fujimori (Peru, 2000), Enron (USA, 2001), Siemens (Germany, 2006), Madoff (USA, 2008), and Gurte (Spain, 2018) are associated with unethical behavior (Transparency International, 2020; Henriques, 2018; Walkins, 2003). In response to the economic and social impact of business fraud and gross negligence, the Association to Advance Collegiate Schools of Business (AACSB) required business ethics to be included in the overall curriculum to satisfy accreditation standards (Orms, 2016). As a business school in pursuit of the AACSB accreditation, the college of this study recognized the need to incorporate ethics into the business curriculum. In fact, the development of ethical perspectives was directed by the college administration (Appendix A).

\section{Research Design}

Two research instruments were selected to assess correlations between the variables of passion, perseverance, self-awareness and ethical behavior. The first research instrument was developed by Professor Angela Duckworth of the University of Pennsylvania. Duckworth has conducted social 
science research on the relationship of grit to personal success for more than 15 years. She defines grit as the "tendency to sustain interest in and effort toward very long-term goals" (Duckworth, Peterson, Matthews, \& Kelly, 2007). She explains the concept of grit as possessing two variables, passion and perseverance, which are measured in the Duckworth's Grit Survey (Appendix B) using a 10-point* Likert-Type questionnaire (Note: Duckworth's first grit survey used a 12-point Likert-Type questionnaire (Duckworth \& Quinn, 2009)). Passion is measured through the survey's odd questions, and perseverance through its even questions. In this study, use of the term total grit encompasses the two components of Duckworth's grit, passion and perseverance.

The Authentic Leadership Questionnaire (ALQ) developed by Avolio, Gardner, and Walumbwa (2007) provided a measurement of self-awareness and ethical behavior (Appendix C). The survey contained eight questions; four questions (odd) were used to measure leadership self-awareness, and the remaining four (even) assessed ethical behavior. In this study, use of the term total leadership encompasses the two components, self-awareness and ethical behavior. Figure 1 depicts the correlations assessed between the four behavior attributes.

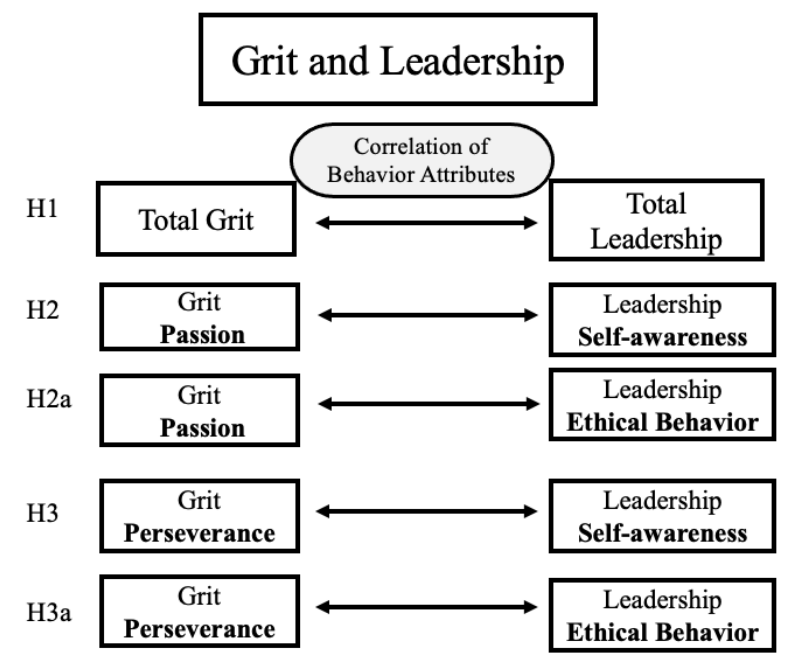

Figure 1 Grit variables to Leadership variables

\section{Hypotheses}

- H1: Students scoring high in their self-assessment of total grit will score high in their selfassessment of total leadership.

- H2: Students scoring high in their self-assessment of grit-passion will score high in their selfassessment of leadership self-awareness.

- H2a: Students scoring high in their self-assessment of grit-passion will score high in their self-assessment of leadership ethical behavior.

- H3: Students scoring high in their self-assessment of grit-perseverance will score high in their self-assessment of leadership self-awareness.

- H3a: Students scoring high in their self-assessment of grit-perseverance will score high in their self-assessment of leadership ethical behavior. 


\section{Methodology}

This longitudinal study examined the relationship of grit levels to self-perceptions of leadership ability. The Duckworth Grit Survey (Appendix B) was chosen as a quantitative device for measuring two behavior variables, passion and perseverance, while the ALQ (Appendix C) was selected to measure self-awareness and ethical behavior. The first phase of the survey was conducted in July 2014. The Duckworth Grit Survey was administered to all first-year students at Nichols College. A first year 100level college class called First Year Professional Development Seminar (PDS), was chosen as the course in which to administer the Duckworth Survey. Instructions were distributed to all teachers of First Year PDS prior to survey execution (Appendix D). By coordinating with the head of the PDS program, all first-year students completed the Duckworth survey within a 5-day academic window.

The second phase of the survey began in 2018. The Duckworth Grit Survey and ALQ were readministered to all seniors at Nichols College. The intent was to measure the changes in the Grit Survey responses of the students from their freshman to senior years. The Duckworth Survey was administered to fourth-year students during a 400-level college class, called Senior Professional Development Seminar (PDS). Prior to survey execution, instructions (Appendix D) were distributed to all teachers of the seminar. For seniors, the ALQ was added at the end of the Grit survey. Through coordination with the head of the PDS program, all seniors completed the Duckworth and ALQ surveys within a 5-day academic window. There were no make-up opportunities for students who missed the initial survey administration.

To maintain confidentiality, names were not attached nor associated with the completed surveys. A survey number was used only as a way to track surveys. Student demographics were derived from the records obtained from the Admissions Office of the college. Table 1 shows information on the 2014 student cohort, initially comprised of 401 students. Four years later, 202 students from this cohort remained at the college.

Table 1 Student Demographics $(2014,2018)$

\begin{tabular}{|l|l|l|l|l|}
\hline & Starting & $\%$ & +4 years & $\%$ \\
\hline Female & 125 & $31.1 \%$ & 79 & $39.1 \%$ \\
\hline Male & 276 & $68.8 \%$ & 123 & $60.8 \%$ \\
\hline Total & 401 & $100 \%$ & 202 & $100 \%$ \\
\hline White & 323 & $80.5 \%$ & 172 & $85.1 \%$ \\
\hline Black & 29 & $7.2 \%$ & 10 & $5 \%$ \\
\hline Hispanic & 26 & $6.5 \%$ & 10 & $5 \%$ \\
\hline Other & 20 & $5.7 \%$ & 10 & $5 \%$ \\
\hline Total & 401 & $100 \%$ & 202 & $100 \%$ \\
\hline
\end{tabular}


The research design also included documentation of declared academic majors of the 2014 cohort, information valuable for future studies. This information is attached as Appendix E. Through the PDS program, 324 first-year students in 2014 were surveyed (Figure 2). In the fall of 2018, seniors who served as initial respondents when they were in their freshman year were re-surveyed (Figure 3), allowing for a comparison of grit scores between 2014 and 2018. Of the initial number of first-year students captured in the survey in 2014 ( $N=324), 137$ seniors retook the survey in 2018.

\section{Results}

Of the 401 first-year students available in 2014, we received Grit Surveys responses from 324 students (80.8\% response rate). Figure 2 depicts the distribution of these students' grit scores from the Duckworth Survey.

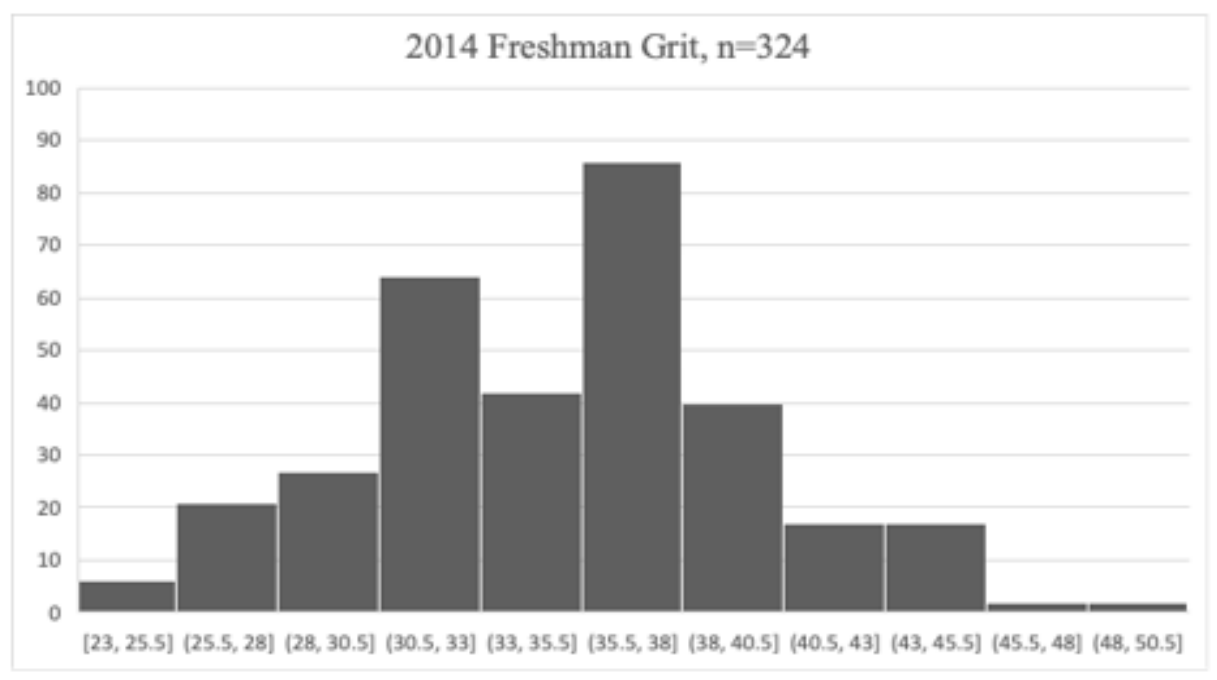

Figure 2 Freshman Grit Histogram

The Grit score was normally distributed with a mean of 35.5 and a standard deviation of 4.8. Among the 324 first-year students that participated in the study in 2014, 137 took the Grit survey again in 2018 during their senior year (42.3\% retention rate: $57.7 \%$ dropout rate). The following histogram presents the distribution of Grit scores for the senior returners.

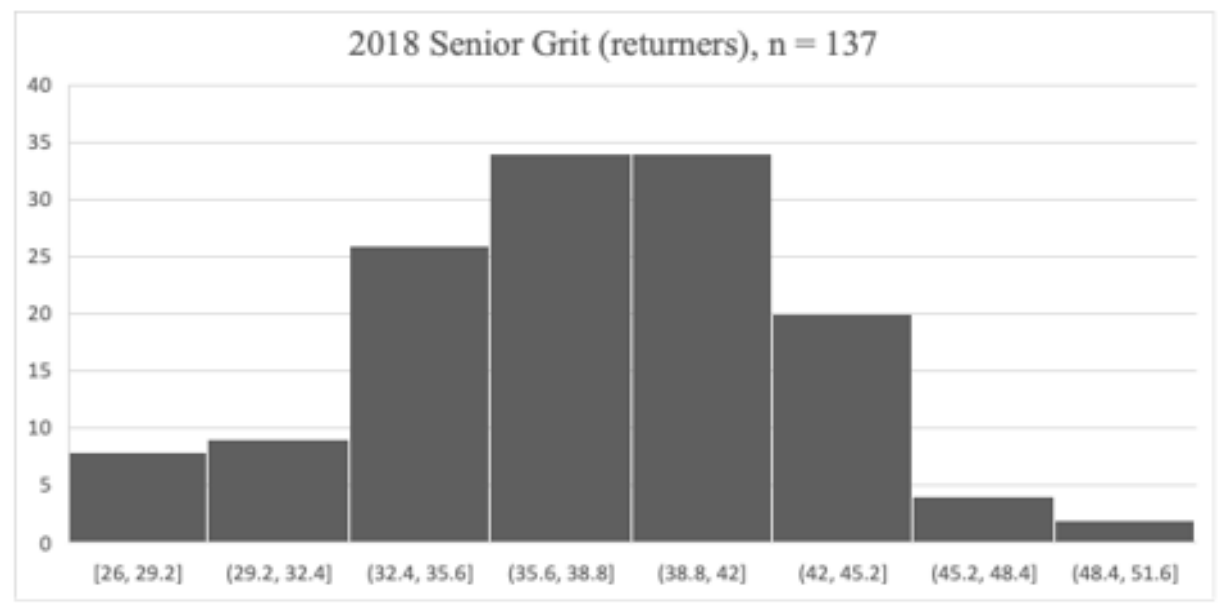

Figure 3 Senior Grit Histogram 
The distribution was again approximately normal, with a higher mean of 37.7 and a standard deviation of 4.8. A paired t-test for the 137 returning students showed that they had significantly higher grit the second time they completed the survey $(p<0.00001)$. Also considered separately were students' scores in the components of Grit, Passion, and Perseverance, as well as in the components of Leadership, Ethics, and Self-Awareness. Table 2 presents the correlation matrix showing the correlations among these variables. These are all positive and significant linear correlations. Perseverance to selfawareness has the strongest correlation, followed by perseverance to ethical behavior $(\mathrm{N}=137)$.

Table 2 Correlations of Grit and Leadership Variables

\begin{tabular}{|l|c|c|c|c|c|c|c|c|c|}
\hline & $\begin{array}{c}\text { FY } \\
\text { Grit }\end{array}$ & FY Pass & $\begin{array}{c}\text { FY } \\
\text { Persev. }\end{array}$ & $\begin{array}{c}\text { Snr } \\
\text { Grit }\end{array}$ & $\begin{array}{c}\text { Snr } \\
\text { Pass }\end{array}$ & $\begin{array}{c}\text { Snr } \\
\text { Persev. }\end{array}$ & Lead & Ethic & $\begin{array}{c}\text { Self } \\
\text { Aw }\end{array}$ \\
\hline FY Grit & 1.00 & & & & & & & & \\
\hline FY Passion & 0.83 & 1.00 & & & & & & & \\
\hline FY Perseverance & 0.76 & 0.26 & 1.00 & & & & & & \\
\hline Snr Grit & 0.54 & 0.50 & 0.34 & 1.00 & & & & & \\
\hline Snr passion & 0.49 & 0.54 & 0.21 & 0.87 & 1.00 & & & & \\
\hline Snr perseverance & 0.41 & 0.28 & 0.38 & 0.80 & 0.41 & 1.00 & & & \\
\hline Leadership & 0.14 & 0.05 & 0.18 & 0.39 & 0.26 & 0.41 & 1.00 & & \\
\hline Ethical Behavior & 0.05 & 0.01 & 0.08 & 0.29 & 0.20 & 0.30 & 0.84 & 1.00 & \\
\hline Self-Awareness & 0.18 & 0.07 & 0.22 & 0.35 & 0.23 & 0.38 & 0.82 & 0.38 & 1.00 \\
\hline
\end{tabular}

- Senior Grit is more positively correlated $(r=0.39$ versus $r=0.14)$ with Leadership than First Year Grit.

- Among the Senior Grit components:

$\circ$ Perseverance $(r=0.41)$ is more strongly correlated with Leadership than Passion ( $r$ $=0.26$ ).

- Perseverance $(r=0.38)$ is more strongly correlated with the Self-Awareness component of Leadership than with Ethics $(r=0.30)$.

- Perseverance $(r=0.18)$ has the closest correlation with Leadership, compared to any other component of First Year Grit. In particular, Perseverance correlates most strongly with Self-Awareness ( $r=0.22)$.

Due to the large sample size $(n=137)$ all correlations were considered statistically significant.

\section{Discussion}

Since the start of research on the correlation between self-perceptions of grit and leadership, the college of the study has been supportive and cooperative. Time was scheduled within first and fourth- 
year courses to administer research surveys. Students and faculty were agreeable and accommodating. Opportunities were extended by the Vice President of Academic Affairs to present seminars of the ongoing findings of the scholarship. Most importantly, collaboration was extended across all departments of the college providing oft needed encouragement and recommendations.

Like many academic explorations this research mutated with maturity. Of interest in the first year of this longitudinal study was the impact of grit on academic success as measured by Grade Point Average (GPA). This focus aligned with an institutional emphasis to understand whether grit could impact firstyear student retention.

Student GPAs for the first four semesters were tracked within the 137-student group that participated in the study during their first and fourth (senior) years. First Year Grit correlated positively with all four semester's GPAs. Senior Grit most notably correlated more strongly with GPA. Table 3 lists the correlation coefficients between first year Grit, senior year Grit, and Semester GPA. The correlation of grit with GPA is of future interest in this longitudinal study.

Table 3 Grit and GPA

\begin{tabular}{|l|c|c|}
\hline & FY Grit & Senior Grit \\
\hline Fall 2014 GPA & 0.15 & 0.31 \\
\hline Spring 2015 GPA & 0.06 & 0.25 \\
\hline Fall 2015 GPA & 0.17 & 0.35 \\
\hline Spring 2016 GPA & 0.15 & 0.30 \\
\hline
\end{tabular}

In the second year of the study, it was recognized that GPA was just one of many aspects of the behavioral process common to a college experience, and it was determined that the variables of that process, not limited to GPA, were of most interest. Copious research has been conducted in the last fifty years on the impact of the college experience to behavior. Burns (1978) examined the transformational effect of empowerment, collaboration, and trust. Block (1993) addressed the importance of accountability. Rogers (1980) scrutinized behaviors designed to alter self-esteem. Carlopio (1994) took a holistic view of the organizational process to create connectedness and balance. Building upon this rich foundation of research, this study selected four variables of interest: passion/perseverance and self-awareness/ethical behavior. It was determined that these four variables encompass a large array of college experiences and student behaviors. Table 4 depicts the variable/behavior association. 
Samborowski, Price, Practico/The Correlation between Grit and Leadership

Table 4 Association of Variables to Behavioral Outcomes

\begin{tabular}{|l|l|}
\hline \multicolumn{1}{|c|}{ Variables } & \multicolumn{1}{c|}{ Behavioral Outcomes } \\
\hline Passion & $\begin{array}{l}\text { Selection of major or course of study } \\
\text { Determination of career choice }\end{array}$ \\
\hline Perseverance & $\begin{array}{l}\text { Achievement of a four-year degree } \\
\text { Commitment to a career path }\end{array}$ \\
\hline Self-awareness & $\begin{array}{l}\text { Recognition and refinement of strengths and weaknesses } \\
\text { Matching self-concept to appropriate career path }\end{array}$ \\
\hline Ethical Behavior & $\begin{array}{l}\text { Academic honesty } \\
\text { Future business decisions and conduct }\end{array}$ \\
\hline
\end{tabular}

\section{Conclusion}

As presented in Figures 2 and 3 and Table 2, there was an increase in Grit over the course of the college experience. It is posited that students' senior Grit scores more accurately represent their grittiness. If Grit is considered as being invariant, then the measurements taken from freshmen and senior years tell us the students' perception of their own Grit level at two points in their lives. It is the selfperception that changes, not the Grit level. Indeed, enhanced self-awareness should be viewed as a byproduct of the college experience, a circumstance supported by the findings of this study.

However, if Grit is considered malleable and encouraged through intervention as Eskreis-Winkler (2015) contends, the challenge becomes to discovery those variables or processes that impact upon the growth of Grit. In this well-intentioned process, caution must be taken as to not develop interventions that result in a Hawthorne Effect from exercises designed and publicized as a means to enhance Grit. With this consideration in mind, future research should examine methods and techniques to fortify Grit.

Additionally, this study found that Grit is positively correlated to academic success and a positive selfperception of leadership ability. Again, it is offered that the relatively secure experiential and experimental process afforded by four years of college is the catalyst of this outcome. This finding is supported by past studies of Grit and leadership association with the maturation process and adolescent development (Chen, 2011; Ewing, 2009; Hinkle, 2018; Lawrence, 2018; Lu \& Shih, 1997; Turner, 1992). College provides opportunities for growth in self-awareness, practice of ethical behavior, discovery of passion and practice of perseverance. Accordingly, the four variables of this study are rich concepts for continued study.

Within the vibrant behavioral Petri dish of the college environment, there are many opportunities for further research on the dynamic interactions between Grit and leadership. This study found a strong correlation between perseverance and self-awareness and a second strong relationship between perseverance and ethical behavior. Additional research is needed to ascertain why perseverance vice passion is the stronger component of Grit when coupled with self-awareness and ethical behavior. 
What is it about a college student and the college environment that more strongly links perseverance to those two variables? What specific activities, club membership, academic discipline, gender, political leaning, or world view, promotes a stronger correlation between perseverance and selfawareness? Additionally, is the second strongest correlation (perseverance to ethical behavior) influenced by the business school where the study took place? Would similar correlations exist amongst undergraduates at a liberal arts college?

Finally, why is the passion component of Grit correlated weaker to self-awareness and ethical behavior than the perseverance component of Grit? Is passion more in flux during the college years than perseverance or were the leadership variables of this study causal determinants for the lower correlations? Additional research juxtaposing different leadership variables to passion and perseverance are in order.

Appendix A: Nichols College Mission Statement

Appendix B: Duckworth Grit Survey

Appendix C: Authentic Leadership Questionnaire

Appendix D: Grit Survey Instructions for PDS teachers

Appendix E: Selected college majors, 2014 cohort

\section{Acknowledgements}

The authors wish to thank the students at Nichols College for their participation in this study and specifically, Paul Parks for his work as a research assistance. Additionally, Alan Reinhardt is recognized as the initial approval authority for this research. Finally, the language editing assistance of Editage (www.editage.com) is acknowledged and lauded.

\section{References}

Admissions Office, Nichols College (2020). Student demographics. Emily Reardon, 508-213-2275.

Alutto, J.A., \& Acito, F. (1974). Decisional participation and sources of job satisfaction: A study of manufacturing personnel. Academy of Management Journal, 17, 170-167.

Antonakis, J., Cianciolo, A.T., \& Sternberg, R.J. (Eds). (2004). The nature of leadership. Thousand Oaks, CA.

Astin, A. (1993). What matters in college? Four critical years revisited. San Francisco: Jossey Bass.

Avolio, B.J., Gardner, W.L., \& Walumbwa, F.O. (2007). Mind Garden. License fee purchased.

Bass, B. (1990). The Bass \& Stogdill's Handbook of Leadership: Theory, research \& managerial applications, 3rd ed. The Free Press, New York.

Blau, P.M. (1964). Exchange and power in social life. New York: Wiley.

Block, P. (1993). Stewardship: Choosing service over self-interest. San Francisco: Berrett-Koehler.

Bornstein, R.F. (1999). Objectivity and subjectivity in psychological science: Embracing and transcending psychology's positivist tradition. The Journal of Mind and Behavior, 20(1), 1-16.

Burns, J.M. (1978). Leadership. New York: Harper \& Row.

Carlopio, J.R. (1994). Holism: A philosophy of organizational leadership for the future. Leadership Quarterly, 5, $297-307$.

Chen, W. (2011). How education enhances happiness: Comparison of mediating factors in four East Asian countries. Social Indicators Research, 106, 117-131. 


\section{Samborowski, Price, Practico/The Correlation between Grit and Leadership}

Colbert, A.E., Judge, T.A., Choi, D., \& Wang, G. (2012). Assessing the trait theory of leadership using self and observer ratings of personality: The mediating role of contributions to group success. The Leadership Quarterly, 23(4), 670-685.

Colgate University (2020). Mission Statement. Retrieved from https://www.colgate.edu/about/mission-statement

Conger, J.A., \& Kanungo, R.N. (1987). Toward a behavioral theory of charismatic leadership in organizational settings. Academy of Management Review, 12(4), 637-647.

Darmouth College (2020). Mission Statement. Retrieved from https://home.dartmouth.edu/mission-statement.

Dary, E.T. (2012). Intellectual college development related to alumni perceptions of personal growth. Research \& Practice in Assessment, 7, 41-49.

Daemen College (2020). Mission Statement. Retrieved from https://www.daemen.edu/about/leadership/missionstatement.

Duckworth, A.L., Peterson, C., Matthews, M.D., \& Kelly, D.R. (2007). Grit: Perseverance and passion for long-term goals. Journal of Personality and Social Psychology, 9, 1087-1101.

Duckworth, A.L., \& Quinn, P.D. (2009). Development and validation of the short grit scale (Grit-S). Journal of Personality Assessment, 91(2), 166-174.

Duckworth, A. (July 2020). Armchair Expert with Dax Shepherd, Podcast. Episode 230.

Dugan, J.P. (2007). Developing leadership capacity in college students: Findings from a National study. Multi-Institutional Study of Leadership, College Park, Maryland.

Eskreis-Winkler, L. (2015). Building grit. University of Pennsylvania.

Ewing, J. C., Bruce, J. A., \& Ricketts, K. G. (2009). Effective leadership development for undergraduates: How important is active participation in collegiate organizations. Journal of Leadership Education, 7(3), 118-132.

Gergen, K.J., \& Taylor, M.G. (1969). Social expectancy and self-presentation in a status hierarchy. Journal of Experimental Social Psychology, 5, 79-92.

Graen, G. (1976). Role making processes within complex organizations. In M.D. Dunnette (ed.), Handbook of industrial and organizational psychology. Chicago: Rand McNally.

Green, M. (2018). Know thyself: The value and limitations of self-knowledge. Routledge Press. London.

Haas, H.G., Tamarkin, B. (1992). The leader within. New York: Harper Business.

Harvard College (2020). Mission Statement. Retrieved from https://college.harvard.edu/about/mission-vision-history

Henriques, D.B. (2018). A case study of a con man: Bernie Madoff and the timeless lessons of history's biggest Ponzi scheme. Social Research, 85(4).

Hersey, P., \& Blanchard, K.H. (1969). Life cycle theory of leadership. Training \& Development Journal, 23, 26-34

Hinkle, R.K. (2018). Increasing student self-awareness to prepare tomorrow's leaders. International Journal of Education Research, 13(1), 42-54.

Homans, G.C. (1958). Social behavior as exchange. American Journal of Sociology, 63, 597-606.

Hopmeyer, A., Troop-Gordon, W., Medovoy, T. et al. (2017). Emerging adults' self-identified peer crown affiliations and college adjustment. Social Psychology Education, 20, 643-667.

House, R. J., Dorfman, P.W., Javidan, M., Hanges, P.J., \& Sully deLuque, M.F. (2013). Strategic leadership across cultures: The GLOBE study of CEO leadership behavior and effectiveness in 24 countries. Washington DC: Sage Publications.

Judge, T.A., \& Long, D.M. (2012). Individual differences in leadership. In D.V. Day \& J. Antonakis (Eds.), The nature of leadership (2nd ed.) Thousand Oaks, CA: Sage Publications.

Kouzes, J.M. \& Posner, B.Z. (1987). The leadership challenge. San Francisco: Jossey-Bass.

Lawrence, E., Dunn, M.W., Weisfeld-Spolter, S. (2018). Developing leadership potential in graduate students with assessment, self-awareness, reflection and coaching. Journal of Management Development, 37(8), 634-651.

Lu, L. \& Shih, J.B. (1997). Sources of happiness: A qualitative approach. The Journal of Social Psychology, 137(2), 181-187. 
March, J.C., \& Simon, H.A. (1958). Organizations. New York: Wiley.

McDaniel College (2020). Mission Statement. Retrieved from https://www.mcdaniel.edu/about-us/mission-historyleadership.

Meens, D. (2013). Philosopher, Know Thyself: meta-philosophical and methodological reflection in philosophy of education as requisite for successful interdisciplinary. Philosophy of Education Yearbook, 336-375

Miller, K.I., \& Monge, P.R. (1986). Participation, satisfaction, and productivity: A meta-analytic review. Academy of Management Journal, 29, 727-753.

Murphy, A.J. (1941). A study of the leadership process. American Sociological Review, 6, 674-687.

Northouse, P.G. (2012). Introduction to leadership: Concepts and practice. 2nd edition. Thousand Oaks, CA: Sage Publications.

Northouse, P. G. (2018). Introduction to leadership: Concepts and practice. 4th edition. Thousand Oaks, CA: Sage Publications.

Occidental College (2020). Mission Statement. Retrieved from https://www.oxy.edu/about-oxy/mission.

Orms, C.M. (2016). Developing the personal ethics code: A key element of an effective business ethics course. Business Education Innovation Journal, 8(2), 51-58.

Padyk, O.M., Basynskay, Y.V., \& Nyhvydovech, I.G. (2017). Key performance factors in behavioral theories of leadership. Leadership and Management, 4(2), 99-107.

Palisoc, A.J., Matsumoto, R.R., Ho, J., Perry, P.J., Tang, T.T., \& Ip, E.J. (2017). Relationship between grit with academic performance and attainment of postgraduate training in pharmacy students. American Journal of Pharmaceutical Education, 81(4), 1-10.

Park, D., Tsukayama, El., Yu, A., \& Duckworth, A.L. (2020). The development of grit and growth mindset during adolescence. Journal of Child Psychology, 198.

Raad, B.A. (2000). The Big Five personality factors: The psycholexical approach to personality. Seattle, WA: Hogrefe \& Huber Publishers.

Reddin, W.J. (1967). The 3-D management style theory. Training and Development Journal, 23(5), 8-17.

Richardson, J.C., Ashby, I., \& Alshammari, A.N. (2019). Faculty and instructional designers on building successful collaborative relationships. Educational Technology Research and Development, 67(4), 855-880.

Rogers, C.R. (1980). A way of being. New York: Houghton Mifflin.

Rost, J.C. (1993). Leadership development in the new millennium. Journal of Leadership Studies, 1, 92-110.

Schriesheim, C.A., \& Kerr, S. (1977). Theories and measures of leadership: A critical appraisal of present and future directions. In J.G. Hunt \& L.L. Larson (eds.) Leadership: The cutting edge. Carbondale: Southern Illinois University Press.

Stenius, K., Makela, K., Milovsky, M., \& Gabrhelik, R. (2017). Chapter 8: How to write publishable qualitative research. Ubiquity Press, 155-172.

Stogdill, R.M. (1950). Leadership, membership and organization. Psychological Bulletin, 47, 1-14.

Stogdill, R.M. (1975). The evolution of leadership theory. Proceedings, Academy of Management. New Orleans.

Thibaut, J.W., \& Kelley, H.H. (1959). The social psychology of groups. New York: Wiley.

Transparency International (2020). https://www.transparency.org/en/news/25-corruption-scandals\#. Retrieved online, 15 August 2020.

Turner, G.Y. (1992). College students' self-awareness of study behaviors. College Student Journal, 26(1), 129-134.

Tyree, T.M. (1998). Designing an instrument to measure socially responsible leadership using the social change model of leadership development. Dissertation. University of Maryland.

Vecchio, R.P. (1987). Situational leadership theory: An examination of a prescriptive theory. Journal of Applied Psychology, $72,444-451$. 
Samborowski, Price, Practico/The Correlation between Grit and Leadership

Walkins, S.S. (2003). Ethical conflicts at Enron: Moral responsibility in corporate capitalism. California Management Review, 45(4), 6-19.

Yukl, G. (1971, July). Toward a behavioral theory of leadership. Organizational Behavior and Human Performance, 6(4), 414-440. 


\title{
Appendix A
}

\author{
Mission Statement
}

Approved by the Board of Trustees

October 20, 2018

Within a supportive community, Nichols College transforms today's students into tomorrow's leaders through a dynamic, career-focused business and professional education.

To support its mission, Nichols College

- Offers an experiential business curriculum with a strong liberal arts foundation that is enhanced by the scholarship of practice and pedagogy.

- Integrates research and scholarship into the student experience programs and activities that cultivate and enhance professional skills and readiness.

- Develops the communication and critical thinking abilities, the ethical and cultural perspectives, and the necessary teamwork skills that are required of leaders in a global economy. 
Samborowski, Price, Practico/The Correlation between Grit and Leadership

\section{Appendix B}

\section{Item Grit Scale Survey*}

\section{Student ID number:}

Note: This is a voluntary exercise. If you do not wish to participate, just sit back in your seat and quietly relax.

Please put your student ID number on this survey. Do not put your name on this survey. We do NOT associate a student ID number with a name. The ID helps us only to identify a survey. The results of this survey are maintained in strict confidentiality.

Respond to the items below with the most accurate match. There are no right or wrong answers.

Mark your selection with an " $X$ " through the appropriate box.

1. New ideas and projects sometimes distract me from previous ones.

?ㅇ? Very much like me

의? Mostly like me

의 Somewhat like me

?] Not much like me

?]? Not like me at all

2. Setbacks don't discourage me. I don't give up easily.

?]? Very much like me

의? Mostly like me

의? Somewhat like me

?] Not much like me

[?] Not like me at all

3. I often set a goal but later choose to pursue a different one.

?]? Very much like me

의? Mostly like me

?궁 Somewhat like me

?]? Not much like me

?ㅇ? Not like me at all

4. I am a hard worker.

의? Very much like me

의? Mostly like me 
[?]? Somewhat like me

?]? Not much like me

?ㅇ? Not like me at all

5. I have difficulty maintaining my focus on projects that take more than a few months to complete.

?ㅇ?ㅇ Very much like me

ㅇ?무 Mostly like me

[?] Somewhat like me

[?] Not much like me

?으 Not like me at all

6. I finish whatever I begin.

?]? Very much like me

?]? Mostly like me

[?]Somewhat like me

?] Not much like me

?? ? Not like me at all

7. My interests change from year to year.

?]? Very much like me

?]? Mostly like me

[?]Somewhat like me

?? ? Not much like me

?? ?

8. I never give up.

의? Very much like me

의? Mostly like me

의 Somewhat like me

[?] Not much like me

의 Not like me at all

9. I have been obsessed with a certain idea or project for a short time but later lost interest.

[?] Very much like me

[?] Mostly like me

?]? Somewhat like me

[?] oㅏ much like me

?]? Not like me at all

10. I have overcome setbacks to conquer an important challenge. 
Samborowski, Price, Practico/The Correlation between Grit and Leadership

?]? Very much like me

의? Mostly like me

[?] Somewhat like me

?]? Not much like me

?]? Not like me at all

*Duckworth, A.L., Peterson, C., Matthews, M.D., \& Kelly, D.R. (2007). Grit: Perseverance and passion for longterm goals. Journal of Personality and Social Psychology, 9, 1087-1101. 


\section{Appendix C}

\section{8-Item Leadership Survey*}

\section{Student ID number:}

Think of yourself as a leader, either on campus or off, in your personal life or work.

Respond to the items below with the most accurate match. There are no right or wrong answers.

Mark your selection with an " $X$ " through the appropriate box.

1. As a leader, my actions are consistent with my beliefs

?? ? Not at all

의? Once in a while

[?] Sometimes

의? Fairly often

?]? Frequently, if not always

2. I make decisions based on my understanding of a universal "right" and "wrong"

?] ? Not at all

?]? Once in a while

ㅇ?구 Sometimes

?궁 Fairly often

?]? Frequently, if not always

3. As a leader, I ask my team to act in accordance with their personal values

?? ? Not at all

[?] Once in a while

으무 Sometimes

ㅇ?로 Fairly often

?]? Frequently, if not always

4. I make difficult decisions based on my understanding of "truth" and "fairness"

?구 Not at all

?]? Once in a while

의? Sometimes

?]? Fairly often

?]? Frequently, if not always 
Samborowski, Price, Practico/The Correlation between Grit and Leadership

5. As a leader, I seek feedback to improve interactions with others

?ㅇ? Not at all

?] Once in a while

ㅇ?구 Sometimes

ㅇ?르 Fairly often

?]? Frequently, if not always

6. As a leader, I can accurately describe how others view my capabilities

?의 Not at all

의? Once in a while

미의 Sometimes

으의 Fairly often

??] Frequently, if not always

7. As a leader, I know my strengths and weaknesses in all areas

?? ? Not at all

?]? Once in a while

구늘 Sometimes

[?]? Fairly often

?]? Frequently, if not always

8. As a leader, I understand the impact of my actions on others

?의 Not at all

?]? Once in a while

ㅇ?요 Sometimes

?굴 Fairly often

?]? Frequently, if not always

Samborowski-Price Leadership Survey. Items influenced and modified from the work of Bruce J. Avolio, William L. Gardner \& Fred O. Walumbwa (2007, Mind Garden). License fee purchased. 


\section{Appendix D}

\section{Grit Survey}

Instructions for Teachers of Senior PDS

Nichols College is involved in a longitudinal study on the correlation of grit to perceptions of leadership. This study is supported by our College President, Dr. Susan Engelkemeyer. Your help with this research is important and greatly appreciated.

Please administer the attached grit survey to every student in your PDS class.

It is important that all students enter their student ID number on the survey. We do not need their names, just their ID numbers. The ID number is NOT associated to a name and will only be used to identify and track the survey.

Please read page 2 verbatim, to all students. After reading page 2, pass out the survey. When the students have completed the survey have them turn it over on their desks (blank sheet up). When all students are done with their surveys, have them submit them with the blank sheet up (this provides a level of confidentiality for the students).

Please collect all surveys and place them in the supplied manila envelope and return to my mailbox at Conant Hall or my office, NAB 336.

Thank you in advance for your support in this research.

Sincerely,

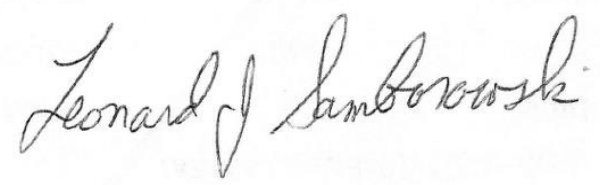

Len Samborowski 
Samborowski, Price, Practico/The Correlation between Grit and Leadership

Page 2

(Please read verbatim to the students)

Doctor Angela Duckworth, University of Pennsylvania, defines the psychological term grit as "the tendency to sustain interest in and effort toward very long-term goals."

At Nichols, we are interested in how grit relates to leadership. Accordingly, we are conducting a longitudinal study on the Grit of Nichols College students.

Please fill out the attached Grit Survey to the best of your ability. There are no right or wrong answers to this survey.

It is important that you place your student ID number on this survey. Please understand that we use your student ID number only as a way to track and organize the surveys. Your responses will not be associated with your name nor be discussed outside the limits of this study.

Most of you seniors completed this survey as first year college students. We are now "closing the loop" and comparing your freshmen responses to your current reactions.

We have also added a Leadership Survey, as we are interested in the relationship between your perceptions of Grit to your perceptions of Leadership. Again, complete the leadership survey to the best of your ability. There are not right or wrong answers to the leadership survey.

Thank you for your participation in this important research project. If interested, please feel free to contact Professors Leonard Samborowski or Jay Price for more details.

Please complete the survey now. When you are finished, turn your survey over with the blank side up. Your instructor will collect them from your desk.

Sincerely,

Len Samborowski

Associate Professor

Management Chair

Nichols College 
Appendix E

Majors, 2014 Cohort

\begin{tabular}{|c|c|c|c|c|c|}
\hline Major & $\begin{array}{l}\text { Incoming } \\
\text { Major }\end{array}$ & Percentage & $\begin{array}{c}\text { Graduating degree } \\
\text { (@6 years) }\end{array}$ & Percentage & $\begin{array}{c}\text { Change over } 6 \\
\text { years }\end{array}$ \\
\hline Accounting & 38 & $9.5 \%$ & 19 & $8.7 \%$ & $-50 \%$ \\
\hline $\begin{array}{l}\text { Business } \\
\text { Communication }\end{array}$ & 23 & $5.7 \%$ & 7 & $3.2 \%$ & $-70 \%$ \\
\hline Criminal Justice & 60 & $15 \%$ & 33 & $15.1 \%$ & $-45 \%$ \\
\hline Economics & 1 & $0.2 \%$ & 4 & $1.8 \%$ & $+300 \%$ \\
\hline English & 3 & $0.7 \%$ & 4 & $1.8 \%$ & $+33 \%$ \\
\hline Finance & 17 & $4.2 \%$ & 19 & $8.7 \%$ & $+12 \%$ \\
\hline General Business & 25 & $8.7 \%$ & 27 & $12.3 \%$ & $+8 \%$ \\
\hline History & 3 & $0.7 \%$ & 2 & $0.9 \%$ & $-33 \%$ \\
\hline Human Resources & 6 & $1.5 \%$ & 10 & $4.6 \%$ & $+67 \%$ \\
\hline $\begin{array}{l}\text { Hospitality } \\
\text { Management }\end{array}$ & 7 & $1.7 \%$ & 8 & $3.7 \%$ & $+14 \%$ \\
\hline $\begin{array}{l}\text { International } \\
\text { Business }\end{array}$ & 7 & $1.7 \%$ & 8 & $3.7 \%$ & $+14 \%$ \\
\hline Math & 4 & $1 \%$ & 2 & $0.9 \%$ & $-50 \%$ \\
\hline Management & 14 & $3.5 \%$ & 6 & $2.7 \%$ & $-57 \%$ \\
\hline Marketing & 19 & $4.7 \%$ & 18 & $8.2 \%$ & $-5 \%$ \\
\hline Psychology & 22 & $5.5 \%$ & 12 & $5.5 \%$ & $-45 \%$ \\
\hline $\begin{array}{l}\text { Sport } \\
\text { Management }\end{array}$ & 91 & $22.7 \%$ & 40 & $18.3 \%$ & $-56 \%$ \\
\hline Undecided & 61 & $12.7 \%$ & & $0 \%$ & NA \\
\hline Total & 401 & $100 \%$ & 219 & $100 \%$ & \\
\hline
\end{tabular}


Samborowski, Price, Practico/The Correlation between Grit and Leadership

Author Information

Leonard J. Samborowski, Doctor of Management, University of Phoenix, 2008. Management Chair, Director of MBA Program, Nichols College. Corresponding author. 133 Calkins Road, Woodstock, CT 06281. Leonard.samborowski@nichols.edu and ov1dlen@gmail.com Office phone (508) 213-2257. Cell Phone (774) 219-6996.

Jason Price, PhD, Mathematics, Providence College, 2010. Dean of Liberal Arts, Nichols College. John Pratico, PhD, Psychology, Boston School, 2010. Psychology Program Chair, Anna Maria. 